\title{
Abdelhamid M. Ahmed, Salah Troudi, Susan Riley (eds.): Feedback in L2 English Writing in the Arab World: Inside the Black Box
}

Palgrave, Macmillan, Switzerland, 2020, 251 pages, ISBN 978-3-030-25829-0, Online

ISBN 978-3-030-25830-6. doi: 10.1007/978-3-030-25830-6

Astri Hapsari ${ }^{*}{ }^{*}$, Fahmi Gunawan ${ }^{2}$ and Hazhira Qudsyi ${ }^{1}$

*Correspondence:

astri.hapsari@uii.ac.id

${ }^{1}$ Universitas Islam Indonesia,

Yogyakarta City, Indonesia

Full list of author information

is available at the end of the

article

\section{Introduction}

In a larger context, the issues on students' feedback are usually caused by the ambiguity of feedback given by teachers which makes the students unable to use feedback (Hyland, 2003). Liu and Carless (2006) showcased that many students feel uncomfortable with the accuracy of peer feedback. Hyland and Hyland (2006) revealed that despite the importance of feedback, teachers often perceive that they did not make the most of it. How teachers provide feedback on students' writings is indeed contextually varied because of students' language ability, teacher feedback types and strategies, and feedback quality. A myriad of studies have been addressed on EFL writing in the Arab world (Ahmed \& Abouabdelkader, 2016, 2018a, b). However, there is a scant amount from the literature on exploring feedback practices. The book edited by Ahmed et al. (2020) is a gate in addressing empirical quantitative and qualitative investigations about perceptions and practices on feedback in EFL writing in the Arab world. It is a resourceful book for practitioners and researchers who would like to learn about feedback in EFL writing in the Middle East and North Africa countries in the higher education context.

\section{Review of the book}

Feedback in L2 English Writing in the Arab World: Inside the Blackbox by Abdelhamid M. Ahmed, Salah Troudi, Susan Riley was published by Palgrave. The editors are notable scholars in TESOL education in the Middle East and North Africa countries. The book is a collection of studies that investigate under-researched topics-EFL writing in the Arab world (Hidri et al., 2018), discussing perceptions and practices on feedback in writing. To document different feedback practices in the Arab world,this book is organized into two main sections, perceptions about feedback in L2 English writing and feedback practices in L2 English writing. It highlights how feedback on EFL writing has been implemented in 18 different Middle East and North Africa countries and presents one state of the art discussion, three studies on perceptions about feedback, four studies on feedback author(s) and the source, provide a link to the Creative Commons licence, and indicate if changes were made. The images or other third party material in this article are included in the article's Creative Commons licence, unless indicated otherwise in a credit line to the material. If material is not included in the article's Creative Commons licence and your intended use is not permitted by statutory regulation or exceeds the permitted use, you will need to obtain permission directly from the copyright holder. To view a copy of this licence, visit http:// creativecommons.org/licenses/by/4.0/. 
practices, and as the editors note' the first book of its type to address feedback practices in English as a Foreign Language (EFL) writing in the Arab world' (p.1).

The book begins with a chapter which introduced the issues on feedback in EFL writing. Synthesizing the key findings from the literature review of 18 countries in Arab world, Ahmed discussed prominent issues in writing classrooms, such as: insufficiency of teachers feedback, types of effective and ineffective feedback, students' responses on feedback, using tools or application in delivering feedback. Ahmed argued that because written communication skills in English are twenty-first century skills required by international employers, proficiency in English writing was essential and needed to be shaped in learning through feedback practices.

Part one of the book consists of 3 studies on perceptions about feedback. In chapter 2, Ouahidi and Lamkhanter investigated a Moroccan higher education institution in terms of teachers' feedback in the writing process. This survey study identified the quality of teachers' comments on the writing task and explored 261 fifth semester English major students' perceptions of these comments. The findings revealed that insufficient follow up activities after having feedback makes the students unable to revise their EFL writing. Although this study filled the research gap on how Moroccan university students, situated in a classroom with a huge number of students ranging in 120-160 (p. 40), perceive teachers' feedback, this study still had a limitation because the data were only collected from students as participants. Teachers' opinions related to their feedback practices were not investigated. In chapter 3, drawing on Hyland and Hyland (2006)'s concept of learners as historically and socially active agents and Vygotskys' sociocultural theory, Dehdary and $\mathrm{Al}$-Saadi argued that attention needs to be drawn on languaging which is further described as the 4D model. They elucidated how Omani EFL students perceive the 4D model which includes the four stages of dialogue (supervised-oral languaging), drill (extended practice), discovery, and dialogue (group-oral languaging) assisted noticing and boosted students' engagement with feedback. The students perceived that feedback was sometimes facilitative and preferred to have feedback along with extensive practice. This study also proved that the students' limited linguistic knowledge was scaffolded by language, which served as a mediating tool for students to identify the knowledge gap. Even though this study to some extent was generalisable within a similar context, it had a potential bias due to one of the researchers' role as the class teacher. In chapter 4, Sayed and Curabba assessed process-based writing classrooms at the American University of Sharjah. This survey study investigated Emirati L2 students' perceptions of various feedback practices and explored the faculty's challenge on feedback practices. All feedback practices were perceived as important for both. In particular, students perceived process writing and the feedback contributed to their writing proficiency. A longitudinal study with multiple participants and courseworks at the university was recommended to portray a more comprehensive result on the faculty and students' attitudes towards EFL feedback practices in classrooms with a huge number of students ranging in 72-90.

Part two of the book consisted of four studies on feedback practices. In chapter 5, Zyad and Bouziane explored Moroccan EFL students' view on feedback in their narrative writing in terms of content and form (grammar accuracy) through think-aloud protocols. Six students were selected meticulously and recruited to be participants. Findings revealed that (1) students with higher proficiency performed more self-correction than 
students with lower proficiency, (2) low ability students tended to distrust peer review, (3) the more prominent teachers gave feedback to students, the more willing students revised their drafts, and (4) in delivering feedback, both lecturers and students neglected feedback on content, as a consequence, there were little change in terms of content during draft revision. Meanwhile, in chapter 6, Athimni explored Tunisian university EFL teachers' beliefs on their students' writing assignments. The participants were $121 \mathrm{EFL}$ students and 7 writing teachers. The findings suggested that teachers viewed feedback as corrective or directive and gave a call for training programmes that could help teachers to improve their feedback practice in higher education. Next, in chapter 7, Al-Harbi and Troudi explored supervisors' view on their written feedback to their Saudi postgraduate students at six universities in the UK. Thematic analysis findings suggested that the written feedback focused mainly on content knowledge, criticality, coherence, clarity, structure, vocabulary appropriateness, and grammatical and spelling accuracy. Finally, in chapter 8, Larouz and Abouabdelkader analysed Moroccan university EFL students' beliefs and attitudes towards their dissertation writing skills. A phenomenological approach was employed in order to enable investigations on issues which involved different perspectives. The participants were 25 doctoral students and 15 teachers in four different universities. The study suggested a mismatch between what teachers and students understood about the concept of feedback and offered implications for potential pedagogy.

Troudi and Riley concluded all the previous chapters and gave final remarks in the last chapter. They discussed the similarity of contexts that the countries in the studies presented, in terms of teaching English as a foreign language and learners' sociocultural background and challenges in EFL writing.

\section{Strengths of the book}

As it is summarised from aforementioned discussions, this book offers a number of insights on perceptions about feedback and feedback practices. First, it delivered issues in various writing coursework designs in the Middle East and North African universities on the empirical and practical ground. Second, the studies were presented in easy to digest language, therefore, it scaffolded a novice researcher in EFL writing to learn several research designs on feedback in EFL writing, varying from survey study, narrative inquiry, mixed methods, semi-structured interview with thematic analysis, phenomenological approach with grounded theory. Third, even though all of the studies were conducted in the university, the participants varied from first-year to doctoral students and the faculty in 18 Middle East and North Africa countries. Finally, as readers finish reading a chapter, in addition to learning about how the studies were conducted, they also learn various methods in providing feedback in EFL writing.

\section{Limitations of the book}

On more critical notes, the book could have been more comprehensive had some studies presented also investigated feedback practice and perceptions on feedback in the secondary education context. For readers living outside the Arab world, it is very interesting to know and to learn how the students learn English writing before they enroll in the university. These studies will add perspectives on why English writing is still challenging 
at higher education levels. In addition, the findings of the studies will be more comprehensive if discussions also include how teachers establish alignments between affordances and learner agency to ensure students' engagement in feedback (Han, 2019), especially in classrooms with a huge number of students.

Overall, to us, the readers living outside the Arab worlds, the contributors and the editors of the book have accomplished an excellent job. This book is a highly recommended reference for teachers and researchers in EFL writing to learn and to better understand issues on feedback practices in the Arab world. Some insights learned from this book can be adapted to give feedback in English writing to other EFL contexts.

\section{Abbreviations}

EFL: English as a Foreign Language; L2: A second language, a foreign language, a target language in language education.

\section{Authors' contribution}

Since the manuscript is a book review, no available data or additional materials are attached with the manuscript. This manuscript was not funded by any funding schemes. The authors were granted a letter of confirmation from the Head of Department of English Language Education Universitas Islam Indonesia, the first author's institution, in order to be eligible for a waiver for publication. The letter of confirmation is also acknowledged by the Dean of Faculty of Psychology and Socio-cultural Sciences Universitas Islam Indonesia, the home institution of the first and the third authors. No potential conflict of interest was reported by the authors. The first author is the main writer who wrote, revised and edited the article and the corresponding author. The second and third authors involved in brainstorming, adding some details in the main text, revising and editing. The third author also did initial contact to the journal editorial board via e-mail correspondence to ask permission for a book review slot. The authors would like to thank any parties that help the manuscript submission, review, and publication to the Journal of Second and Foreign Language Education, especially Professor Handoyo Puji Widodo who became the authors' mentor in book review publication workshop and Post-Hallidayan Systemic Functional Linguistics Community for the being a community with strong academic vibe and support which organize the book review workshop. All authors read and approved the final manuscript.

\section{Declarations}

\section{Competing interests}

The authors declare no competing interests.

\section{Author details}

${ }^{1}$ Universitas Islam Indonesia, Yogyakarta City, Indonesia. ${ }^{2}$ Institut Agama Islam Negeri Kendari, Kendari, Indonesia.

Received: 12 May 2021 Accepted: 7 August 2021

Published online: 01 September 2021

\section{References}

Ahmed, A., \& Abouabdelkader, H. (2016). Teaching EFL writing in the 21st century Arab world: Realities and challenges. Palgrave Macmillan.

Ahmed, A., \& Abouabdelkader, H. (2018a). Assessing EFL writing in the 21st century Arab world: Revealing the unknown. Palgrave Macmillan. https://doi.org/10.1007/978-3-319-64104-1.

Ahmed, A., \& Abouabdelkader, H. (2018b). Assessment of EFL writing in Some Arab university contexts: Issues and challenges. In book: Assessing EFL writing in the 21st Century Arab World: Revealing the unknown (p. 33). Palgrave Macmillan. https://doi.org/10.1007/978-3-319-64104-1_1.

Ahmed, A.M., Troudi, S., \& Riley, S. (2020). Feedback in L2 English writing in the Arab world: Inside the Black Box. Switzerland: Palgrave Macmillan.

Han, Y. (2019). Written corrective feedback from an ecological perspective: The interaction between the context and individual learners. System, 80, 288-303. https://doi.org/10.1016/j.system.2018.12.009

Hidri, S., Troudi, S., \& Coombe, C. (2018). Guest editors' introduction. Arab Journal of Applied Linguistics, 3(1), 1-4.

Hyland, K., \& Hyland, F. (2006). Feedback on second language students' writing. Language Teaching, 39(2), 83-101. https:// doi.org/10.1017/S0261444806003399

Hyland, F. (2003). Focusing on form: Student engagement with teacher feedback. System, 31(2), 217-230. https://doi.org/ 10.1016/S0346-251X(03)00021-6

Liu, N. F., \& Careless, D. (2006). Peer feedback: The learning element of peer assessment. Teaching in Higher Education, 11(3), 279-290. https://doi.org/10.1080/13562510600680582

\section{Publisher's Note}

Springer Nature remains neutral with regard to jurisdictional claims in published maps and institutional affiliations. 